ТРУДОВА МІГРАЦІЯ БАТЬКІВ ЯК ЧИННИК ВАЖКОГО ПЕРЕБІГУ АЛКОГОЛЬНОЇ ЗАЛЕЖНОСТІ В ЇХНІХ ДІТЕЙ У ДОРОСЛОМУ ВІЦІ: РЕЗУЛЬТАТИ ДОСЛІДЖЕННЯ

\title{
LABOR MIGRATION OF PARENTS AS A FACTOR IN THE SEVERE COURSE OF ALCOHOL ADDICTION IN THEIR ADULT CHILDREN: RESEARCH RESULTS
}

Відповідно до теорії системної сімейної психотерапії, стосунки між батьками і дитиною є важливим аспектом для формування відчуття благополуччя у дитини. У статті представлено результати емпіричного дослідження, яке мало на меті виявити взаємозв'язок між відсутністю батьків через трудову міграцію, дитячо-батьківськими стосунками та алкогольною залежністю для дітей трудових мігрантів. Ми досліджували зв'язок алкогольної залежності дорослих дітей трудових мігрантів з особливістю їх сприйняття дитячо-батьківських стосунків в батьківській дистантній сім'ї. В дослідженні взяли участь 244 респонденти віком від 20 до 40 років, кожен з яких, за методикою MUST Brief, мав ознаки алкогольної залежності. Респонденти були поділені на такі дві групи: алкозалежні дорослі діти трудових мігрантів; алкозалежні, батьки яких ніколи не виїжджали на заробітки. У ході дослідження використано розроблено нами анкету-опитувальник, методики діагностики дитячо-батьківських взаємин А. Рое і М. Сігельмана в адаптації О.І. Крупської, mест на виявлення алкогольної залежност MUST Brief. Методами оброблення емпіричних даних є кореляційний та односракторний дисперсійний аналіз за критерієм Шефрфе в Statistica. Результати показали, що дітu трудових мігрантів втрачають емоційний контакт із батьком, сприймають його менш люблячим, менш опікуючим і більш відкидаючим, коли він був відсутнім через роботу за кордоном. Любов матері $є$ найменшою, а відкинення нею - найбільшим за трудово міграції обох батьків. Трудова міграція обох батьків пов'язана з тяжчим перебігом алкогольної залежності у їхніх дітей (запійною фоомою алкогольної залежності), більшою кількістю повторних звернень на лікування, прямо пов'язана з фрактом вживання наркотиків. Педагогічна занедбаність дітей через трудову міграцію батьків у минулому чи на актуальний момент накладає негативний відбиток на дитячо-батьківські стосунки між ними і сприяє алкоголізації та вживанню інших психоактивних речовин.

Ключові слова: трудова міграція, діти заробітчан, алкогольна залежність, фоомування алкогольної залежності, дитячо-батьківські стосунки.

According to family systems therapy parents-child relationship is important factor to create a feeling of safety in child. The aim of this paper is to present the results of our empirical research we did to investigate the correlation between parent's labour migration, the parent-child relationship and alcohol addiction of the adult children of migrant workers. We investigated the connections between alcohol addiction of adult children of migrant workers and peculiarity of comprehension their parent-child relationship in nuclear fractured family. 244 people with alcohol addiction aged between 20 and 40 years old were recruited for this study. The cohort was divided into two groups according to the fact of parent's labour migration: alcohol addicted adult children of migrant workers and group with alcohol addiction whose parents never migrated for work. Group 1 was additionally divided into three subgroups: mother's labour migration, father's labour migration and both parents migrated for work. We gathered information using Questioner we did, A. Roe, M. Siegelman, Parent-child relations questionnaire, Michigan Alcohol Screening Test. All analyses were carried out using software package Statistical Package for Social Sciences (SPSS). Adult children of migrant workers loose emotional contact with their father, identify him less loving, less caring and more rejecting if he works abroad. Mother is seen less loving and more rejecting in a case of both parents' labor migration. A positive correlation was found between parents' labour migration and severe course of alcohol addiction in their children and the fact of using psychoactive substances. The most harmful impact labour migration has for children who are both parents migrated for work. The adult children of migrant workers feel themselves neglected because of labour migration of their parents. Parent's labour migration in the past or in the present moment causes negative parent-child relationship and positively influence on formation of alcohol addiction in children. Labour migration causes severe course of addiction and is the factor of using illicit psychoactive substances for the children left behind.

Key words: labour migrants, children left-behind, alcohol addiction, children of migrant workers.
Постановка проблеми. Під час роботи у наркологічному відділенні ми виявили, що значний відсоток пацієнтів (близько 5\%) $€$ дорослими дітьми трудових мігрантів. Ми звернули увагу на те, що це були переважно чоловіки віком від 20 до 35 років, які під час збору анамнезу часто приховували факт трудової міграції батьків. Цікаво, що їх лікування зазвичай оплачували батьки, які контактували з лікуючим лікарем по телефону або приїздили в лікарню. Під час спілкування з лікарем чи психологом поведінка батьків відрізнялась від такої, яка здебільшого притаманна співзалежним родичам молодих пацієнтів: ми не спостерігали сліз, відчуття безпорадності або виправдування поведінки пацієнтів («Він взага- 
лі-то хороший хлопчина», «Колектив на роботі у нього питущий» тощо). Натомість батьки були емоційно стриманими, з холодним розумом вирішували всі необхідні організаційні питання. Характерним проханням від них було таке: «Чи могли б ви потримати тут мого сина подовше?». Ймовірно, брак повноцінної присутності батьків у тривалі або певні (кризові) періоди життя дитини накладає відбиток на дитячо-батьківські відносини і може призводити до алкоголізації в майбутньому. Важливо також зрозуміти, чия відсутність є більш згубною для психіки дитини: матері, батька чи обох батьків. Для з'ясування цих питань і перевірки припущення здійснено психологічне опитування й проведено пілотажне дослідження, з результатами якого можна ознайомитись тут (В.А. Гупаловська, Є.А. Шапочка, 2017 рік). Для дослідження, результати якого ми наводимо у статті, нами були внесені зміни в анкету-опитувальник, зокрема додані запитання про вживання наркотиків.

Аналіз останніх досліджень і публікацій. Трудова міграція як явище соціально-економічне часто розглядається в літературі з позиції впливу на демографічні чи фінансові показники і є характерним для країн, що розвиваються. Однак трудова міграція є потужним психологічним чинником, який впливає на життя сім'ї трудових мігрантів загалом і на залишених вдома дітей зокрема. Членам такої сім'ї неможливо повноцінно спілкуватися один з одним, як зазначає В.В. Шебаніц [12]. Сепарація з матір'ю, батьком чи обома батьками, зміна в розподілі сімейних ролей, ослаблення системи підтримки й адаптація до додаткових ролей знижують показники емоційного благополуччя у залишених вдома дітей [22, с. 199]. Діти, які виховуються в дистантних сім'ях, відносяться дослідниками до групи ризику й мають більший шанс розвинути хімічну чи нехімічну залежність, ніж їхні однолітки, які живуть із батьками постійно. В групу ризику таких дітей відносять Л.В. Боярин, К.Б. Левченко, І.М. Трубавіна, І.І. Цушко, Д.Т. Гошовська, М.В. Самарська. Дослідники з Китаю пов'язують появу інтернет-залежності і факт паління цигарок у дітей із трудовою міграцією батьків [10, с. 21; 18]. Про частіше вживання алкоголю й тютюну цією категорією досліджуваних зазначається в даних досліджень "UNICEF-UNDP" [15]. Незважаючи на інтерес науковців до цієї теми, залишається відкритим питання про те, чи дійсно трудова міграція батьків може бути фактором, який впливає на формування залежності у їхніх уже дорослих дітей.

Характер стосунків неповнолітніх дітей заробітчан із батьками потрапляє в поле уваги дослідників через їх соціальну незахищеність. Зокрема, про жорстоке поводження з боку оточуючих, однокласників, старших дітей, родичів, зловживання алкоголем, зниження успішності у навчанні свідчать $3 \%$ дітей трудових мігрантів [8]. Зазначають також, що ці діти схильні трактувати себе з позиції жертви, частіше піддаються дискримінації в середній та старшій школі, піддаються психологічному насильству у вигляді залякувань і принижень [7; 16]. Досягаючи повноліття, ці діти випадають з поля зору дослідників, оскільки втрачають свій статус соціально не захищеної категорії населення.

За місяці й роки окремого проживання формується відчуження дітей від батьків, а в подальшому - незадоволена потреба в емоційній близькості. Л.В. Боярин вважає, що саме відсутність емоційного контакту з батьками призводить до зловживання ПАР, дезадаптивної поведінки і соматичних захворювань [1, с. 73].

Емоційна депривація дитини як наслідок неможливості задовольнити потребу в любові, підтримці, опіці, спілкуванні з батьками супроводжує дітей трудових мігрантів протягом тривалого часу, зокрема в доповіді Інституту демографії та соціальних досліджень зазначено, що 64\% дітей трудових мігрантів не бачили власних батьків три й більше років [11, с. 272]. Дослідники зазначають серед характерних наслідків від'їзду батьків на заробітки вищий рівень тривожних розладів та депресії [5; 6, с. $14 ; 8$, с. 2; 16, с. 2570], прогули занять [8, с. 2], зниження успішності в навчанні [6, с. 13-14] більший ризик вживання психоактивних речовин $[1$, с. $73 ; 7$, с. $286 ; 6$, с. 14 ; 16, с. 2573]. Серед наслідків емоційної депривації опиняються асоціальна поведінка та різні адикції, про що пише Д.Т. Гошовська [3, с. 76]. Педагогічна занедбаність дітей мігрантів проявляється у нерегулярному харчуванні, збільшенні випадків підліткової вагітності, надмірній вазі тіла, соматичних захворюваннях, довшому проведенні часу перед телевізором чи в Інтернеті [11, с. 272; 24].

Полярно сімейна система може відігравати превентивну роль у формуванні залежностей. Дослідження, проведені в семи європейських країнах, відзначають пряму кореляцію між повними сім'ями та відсутністю звички палити у дітей [17, с. 50]. Угорські вчені зазначають, що авторитетний стиль виховання, особлива чуйність і позитивна ідентифікація з батьками можуть як служити захистом від періодичного вживання алкоголю підлітками, так і впливати на подальше здорове ставлення до алкоголю й паління. Водночас вони зазначають, що хоча батьківський контроль має тенденцію до зниження в середній школі, проте він служить навіть більшим захистом для тих, чиї батьки продовжують здійснювати його в старшій школі в умовах теплої сімейної атмосфери 
й довіри [13, с. 7; 14, с. 353]. Покращення спілкування батьків і дітей відіграє превентивну роль у розвитку ризикованої поведінки останніх, підвищуючи академічні досягнення й самооцінку [20, с. 54].

Ми розуміємо, що не кожне зловживання психоактивними речовинами приводить до формування залежності. 3 іншого боку, особливості сімейних стосунків дітей трудових мігрантів, більша частота зловживання алкоголем, тютюном і наркотиками, віднесення їх дослідниками до групи ризику, а також відсутність даних про вплив заробітчанства на дитячо-батьківські стосунки в дорослому віці загалом і на формування залежності зокрема визначають актуальність теми нашого дослідження.

Залишаються нез'ясованими питання впливу трудової міграції батьків на стосунки з їхніми вже дорослими дітьми і взаємозв'язку заробітчанства батьків із алкогольною залежністю у їхніх дітей у дорослому віці, що зумовило актуальність нашого дослідження.

Постановка завдання. Метою статті $€$ презентація результатів дослідження, проведеного нами у 2017 році за участю 244 респондентів з алкогольною залежністю (MUST Brief >4), з яких 126 осіб є дорослими дітьми трудових мігрантів, а у 118 респондентів батьки ніколи не виїжджали на заробітки за кордон.

Емпіричне дослідження проведено нами у 2017 році за участю пацієнтів реабілітаційних центрів "Step by Step" і «Добро» у місті Львові. Групу досліджуванихсклали 244 особи віком від 20 до 40 років, з яких 238 чоловіків і 6 жінок. У 126 осіб батьки виїхали на заробітки за кордон тоді, коли респонденти ще не досягли повнолітнього віку, у 44 з них (34,92\%) батьки й досі перебували за кордоном на момент опитування. У 54 респондентів за кордоном працював батько, у 46 матір, у 26 - обидва батьки. Всі респонденти були поділені на такі чотири групи відповідно до профілю вживання психоактивних речовин (ПАР): ті, що вживали виключно алкоголь; вживали алкоголь, маючи запої; вживали алкоголь та інші наркотики; вживали алкоголь та інші наркотики, маючи запої. В табл. 1 можна побачити, як розподілилося вживання ПАР у різних групах респондентів.
Виклад основного матеріалу дослідження. За результатами проведеного нами опитування та математико-статистичної обробки даних (однофакторного дисперсійного аналізу з наступним порівнянням за Шеффе-тестом), любов батька з точки зору респондентів $€$ найменш вираженою тоді, коли він виїхав на роботу за кордон, статистично значимою $€$ відмінність із групами респондентів, де за кордон не виїхав ніхто, виїхала матір чи виїхали обидва батьки (М0емп $=29,24$, М1емп $=22,93$, М2емп $=30,96$, МЗемп $=31,62$, $\mathrm{p} \leq 0,05)$ (рис. 1). Опіка батька $\in$ меншою з точки зору респондента тоді, коли батько працював за кордоном порівняно 3 результатом групи, в якій за кордоном працювали обидва батьки (М1емп=21,96, МЗемп=29,85, $\mathrm{p} \leq 0,01)$, відкинення батьком із точки зору респондента $\epsilon$ більшим у групах, де батько працював за кордоном, ніхто з батьків не працював за кордоном, порівняно з групою респондентів, де за кордоном працювала матір (МОемп=26,2, М1емп=29,63, М2емп=19,17, $\mathrm{p} \leq 0,05)$. Алкогольна залежність $€$ найбільш вираженою в групі респондентів, де за кордон виїхав батько, статистично значимою $\epsilon$ відмінність із групою респондентів, де за кордон виїхали обидва батьки (М1емп $=0,88$, МЗемп=0,38, $\mathrm{p} \leq 0,05)$. Любов матері $з$ точки зору респондентів $€$ меншою тоді, коли за кордон виїхали обидва батьки, статистично значимою $є$ відмінність із групами, де за кордон виїхав батько чи не виїхав ніхто з батьків (М0емп=31,56, М1емп=31,56, МЗемп $=24,62$, $\mathrm{p} \leq 0,05)$, відкинення матір'ю з точки зору респондентів $є$ більшим у групі, де обидва батьки працювали за кордоном, порівняно з трьома іншими групами (МОемп=20,56, М1емп=17,29, М2емп=19,91, МЗемп=27,31, $\mathbf{p} \leq 0,05)$.

У разі від'їзду батька збільшується навантаження на матір, зокрема в процесі виховання. Ми припускаємо, що саме через стрес і відсутність стабільності, які переживає родина, погіршується комунікація в сім'ях. Як свідчать дані, жінки, що залишилися вдома з дітьми, звітували про погіршення комунікації між батьком і дітьми [15, с. 22]. Досліджено, що занедбання виховного процесу батьками ("neglectful parenting stile") у підлітковому віці безпосередньо пов'язано з ризиком вживання

Розподіл вживання ПАР між групами

Таблиця 1

\begin{tabular}{|l|l|l|l|l|}
\hline пАР & $\begin{array}{l}\text { Батьки } \\
\text { не працювали } \\
\text { за кордоном }\end{array}$ & $\begin{array}{l}\text { За кордоном } \\
\text { працювала } \\
\text { мати }\end{array}$ & $\begin{array}{l}\text { За кордоном } \\
\text { працював } \\
\text { батько }\end{array}$ & $\begin{array}{l}\text { За кордоном } \\
\text { працювали } \\
\text { обидва батьки }\end{array}$ \\
\hline Алкоголь & $6,78 \%$ & $13,04 \%$ & & \\
\hline Алкоголь (запої) & $15,25 \%$ & $8,69 \%$ & $14,81 \%$ & \\
\hline Алкоголь+наркотики & $59,32 \%$ & $43,48 \%$ & $48,15 \%$ & \\
\hline Алкоголь+наркотики (запої) & $18,64 \%$ & $34,78 \%$ & $37,04 \%$ & $100 \%$ \\
\hline
\end{tabular}




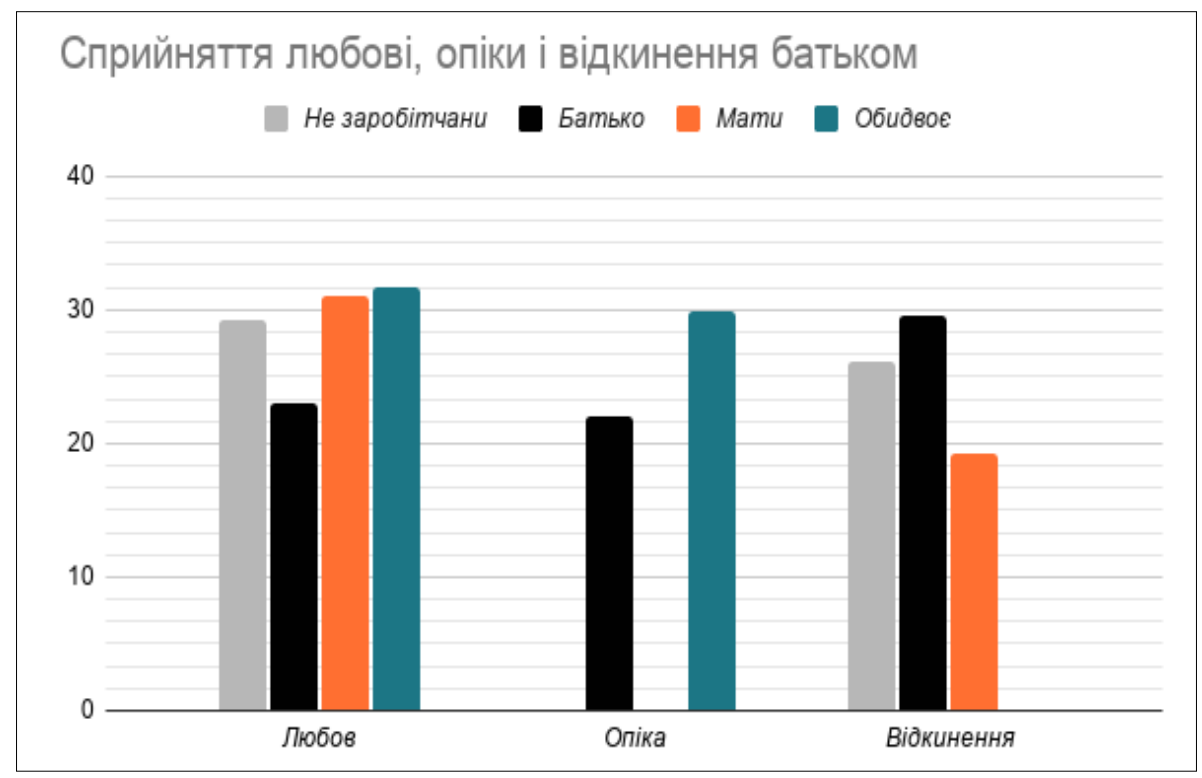

Рис. 1. Сприйняття любові, опіки і відкинення батьком з точки зору респондентів

ПАР підлітками [13, с. 4]. Відомо, що відкидаючий батько, нехтуючий батько і нехтуюча матір можуть бути позитивно пов'язані з алкогольною залежністю у дітей [21, с. 45].

Негативне уявлення про справжнє ставлення матері до респондента (менша її любов та більше відкинення респондента нею) прямо пов'язано з відсутністю обох батьків, тобто відсутність обох батьків у житті респондента через їх перебування за кордоном стає більш критичним фактором депривації, ніж відсутність тільки матері, можливо, сприймається як відповідальність і справа рук матері.

На нашу думку, батьки-заробітчани занедбують виховний процес і не мають змоги виконати свою роль друга, провідника й ментора, навчити ефективному подоланню психологічних бар'єрів у спілкуванні або звичайним способам налагодження контактів. Без батьків дитина залишається з цим завданням наодинці, відчуваючи себе відкиненою, з відчуттям браку опіки й батьківської любові. У разі трудової міграції батьків діти зазнають подвійного впливу негативних стосунків: з одного боку, є відкидаючі, менш люблячі батьки й менш опікуючий батько, з другого боку, наявна відсутність щоденного рутинного контролю. У батьків немає можливості щодня контролювати, тобто позитивно підкріплювати або ситуативно карати, оскільки їх немає поруч. Наявність рутинного контролю з боку батьків формує відчуття власного внутрішнього контролю у дітей. За відсутності одного з батьків або обидвох батьків порушується формування здатності до самоконтролю.

Вживання наркотиків засвідчили респонденти всіх чотирьох груп, проте запійне вживання алкоголю разом зі вживанням нар- котиків $є$ стовідсотковим у групі, де батьки виїхали разом, статистично значимою $є$ відмінність між групами, де батьки не працювали за кордоном, та групою, де батьки працювали там разом (МОемп=0,33, М1емп $=0,52$, М2емп=0,61, МЗемп=1,00, p $\leq 0,01)$. Припускаємо, що діти, чиї обидва батьки виїхали працювати, є найбільш вразливою групою для деструктивного впливу вулиці. Високий рівень стресу потребує ефективних способів копінгу, а саме подолання стресу підлітки називають однією з головних причин для вживання алкоголю і наркотиків [2]. Високий ризик формування алкогольної залежності у людей, які в молодому віці вибирали вживання алкоголю як копінг-стратегію в умовах стресових життєвих подій, доведений незалежними дослідженнями на великих вибірках молодих людей в Ірландії та Америці [19, с. 254; 23, с. 558]. Серед копінг-стратегій дітям трудових мігрантів притаманні пошук соціальної підтримки, втеча-уникання (зокрема, вживання психоактивних речовин), планування, позитивна переоцінка [9, с. 149-150].

Актуальне (на час проведення опитування) перебування батьків на заробітках за кордоном прямо пов'язано зі вживанням наркотиків (значуща кореляція, $r=0,23, p \leq 0,05$ ). Найбільш прогностично сприятливим щодо виникнення запійної алкогольної залежності у дорослих дітей трудових мігрантів є спільне перебування батьків за кордоном, а алкогольної залежності взагалі - трудова міграція батька, що загалом позбавляє дитину необхідного їй у певному віці контролю, дисципліни, тепла та турботи.

За даними кореляційного аналізу (лінійна кореляція Пірсона), трудова міграція батьків прямо пов'язана з наявністю повторних звер- 
нень по професійну допомогу до нарколога чи реабілітаційного центру (статистично значуща кореляція, $r=0,29, p \leq 0,05)$. Актуальне перебування батьків на заробітках за кордоном прямо пов'язане з повторними зверненнями по допомогу у боротьбі із залежністю $(r=0,37, p \leq 0,05)$, алкогольним делірієм в анамнезі $(r=0,25, p \leq 0,05)$, алкогольною епілепсією в анамнезі $(r=0,25, p \leq 0,05)$, дратівливістю $(r=0,23, p \leq 0,05)$, спробами самостійної відмови від вживання $(r=0,23, p \leq 0,05)$. Батьки 3-за кордону часто були ініціаторами лікування, оплачуючи дітям перебування в центрі реабілітації. Водночас факт повторних звернень і тяжкі ускладнення у вигляді алкогольного делірію («білої гарячки»), алкогольної епілепсії зі спробами самостійно впоратися із залежністю свідчать про тяжкий перебіг алкогольної залежності у дорослих дітей трудових мігрантів.

Висновки 3 проведеного дослідження. У проведеному дослідженні дорослі діти трудових мігрантів сприймають власного батька відкидаючим, менш люблячим і таким, що менше опікується ними, втрачають із ним позитивний емоційний контакт. Найсильніше алкогольна залежність виражена в групі, де за кордоном працював батько. Матір постає найменш люблячою і найбільш відкидаючою, коли батьки працювали на заробітках разом, ймовірно, несучи на собі відповідальність за розформовану родину як «берегиня». Від'їзд обидвох батьків у минулому або їх актуальне перебування за кордоном безпосередньо пов'язаний зі вживанням наркотичних речовин їх дітьми. Респонденти із сімей, де за кордоном працювали обидва батьки, мають перебіг алкогольної залежності із запоями, алкогольним делірієм та епілепсією, а звернень на лікування більше, ніж респонденти, батьки яких за кордоном ніколи не працювали. Тяжчий перебіг алкогольної залежності прямо пов'язаний з актуальним перебуванням батьків на заробітках за кордоном.

\section{ЛІТЕРАТУРА:}

1. Боярин Л.В. Причини проявів девіантної поведінки підлітків із сімей трудових мігрантів. Теоретичні і практичні проблеми психології. 2013. № 2 (13). C. 68-75.

2. Вступ у когнітивно-поведінкову терапію. Львів : Свічадо, 2014. 420 c.

3. Гошовська Д.Т. Емоційна депривація як негативний чинник формування патологічної особистості. Особистісне зростання: теорія і практика. Житомир, 2020. С. 76-78.

4. Гупаловська В.А., Шапочка Є.А. Соціально-психологічні чинники алкоголізації дітей трудових мігрантів. Міжнародні Челпанівські психолого-педагогічні читання (у рамках VII Міжнародного фрестивалю «Світ психології: освіта, наука, інновації»). 2017. Вип. 37 (3). Т. I (21). С. 341-354.
5. Міжнародний благодійний фонд «Карітас України», "BrainNet-Working" : Трудова міграція як інструмент інтернаціоналізації. Збірка матеріалів комплексного дослідження трудової міграції та ринків праці. (Іспанія, Італія, Молдова, Україна, Російська Федерація). Львів : Друкарські куншти, 2010.

6. Пігіда В.М. Проблема зовнішньої трудової міграції: соціально-психологічний аспект. Соціальна педагогіка: теорія і практика. 2009. № 4. С. 12-17.

7. Раєвська Я.М. Феномен дистантної сім'ї та ії вплив на особистість підлітка. Проблеми сучасної психології. 2011. Вип. 11. С. 280-290.

8. Самарська М.В. Профрілактика та корекція депресивних станів дітей трудових мігрантів : методичний посібник. URL: https://osvita.ua/doc/files/ news/140/14045/Profilaktika.doc.

9. Сорокоумова Е.А., Цынцарь А.Л. Особенности преодолевающего поведения подростков из семей трудовых мигрантов (на примере приднестровского региона). Известия Самарского научного чентра Российской академии наук. 2013. Т. 15.

10. Соціально-педагогічна та психологічна робота з дітьми трудових мігрантів : навчально-методичний посібник / за ред. К.Б. Левченко, І.М. Трубіанової, І.І. Цушка. Київ : ФОП «Купріянова», 2007. 240 с.

11. Українське суспільство: міграційний вимір : національна доповідь. Київ : Інститут демограсрії та соціальних досліджень ім. М.В. Птухи НАН Украіїни, 2018. 396 c. URL: https://www.idss.org.ua/arhiv/ Ukraine_migration.pdf (дата доступу: 05.11.2020).

12. Шебаніц В.В. Соціально-психологічні аспекти соціалізації дітей - членів транснаціональних сімей. Громадянська освіта. 2012. № 3. URL: http://osvita. khpg.org/index.php?id=1330532710 (дата доступу: 20.12.2020).

13. Tur-Porcar A.M., Jimenez-Martinez J., Vicenta-Escriva V. Substance use in early and middle adolescentce. The role of academic efficacy and parenting. Psychosocial Intervention. 2019. URL: https://www.academia.edu/40077056/Substance_Use_ in_Early_and_Middle_Adolescence_The_Role_of_Academic_Efficacy_and_Parenting.

14. Piko B.F., Balazs M.A. Authoritative parenting style and adolescent smoking and drinking. Addictive behaviors. 2012. Vol. 37 (3). P. 353-356.

15. Children and women left behind in labor sending countries: an appraisal of social risks. Global report on migration and children. UNICEF-UNDP initiative. 2007. URL: https://www.unicef.org/policyanalysis/files/ Children_and_women_left_behind\%282\%29.pdf (дата звернення: $2 \overline{4} .09 .2020)$.

16. Fellmeth G., Rose-Clarke K., Zhao Ch. Health impacts of parental migration on left-behind children and adolescents: a systematic review and meta-analysis. Published online. 2018. December 05. DOI: 10.1016/ S0140-6736(18)32558-3.

17. Griesbach D., Amos A., Currie C. Adolescent smoking and family structure in Europe. Social science and medicine. 2003. Vol. 56 (1). P. 41-52.

18. Cuo J., Chen L., Wang X. The relationship between internet addiction and depression among migrant children and left-behind children in China. Cyberpsychology, behavior and social networking. 2012. Vol. 15 (11). 


\section{ГАБІТУС}

19. Rafnsson F.D., Jonsson F.H., Windle M. Coping strategies, stressful life events, problem behaviors, and depressed affect. Anxiety, stress and coping. 2006. Vol. 19 (3). P. 241-257.

20. Riesch S.K., Anderson L.S., Krueger H.A. Parentchild communication processes: preventing children's health-risk behavior. Journal for specialists in pediatric nursing. 2006. № 11. P. 41-56.

21. Sharma. A. The role of parent-child relationship in the development of alcoholism. Transstellar journal. 2018. DOI: $10.24247 /$ ijhrmrdec20185.

22. Silver A. Families Across Borders: The Emotional Impacts of Migration on Origin Families. International
Migration. 2014. № 52 (3). P. 194-220. DOI: 10.1111/ j.1468-2435.2010.00672.x.

23. Windle M. Coping strategies, drinking motives and stressful life events among middle adolescents: associations with emotional and behavioral problems and with academic functioning. Journal Abnorm. Psychol. 1996. Vol. 105. № 4. P. 551-560.

24. Gao Y., Ping Li L. and others. The impact of parental migration on health status and health behaviors among left behind adolescent school children in China. BMC Public health. 2010. URL: https://bmcpublichealth.biomedcentral.com/articles/ 10.1186/1471-2458-10-56. 